\title{
AN ASSESSMENT OF THE IMPACT OF VARIOUS MACRO- ECONOMIC VARIABLES ON THE MANUFACTURING SECTOR: THE CASE OF THE VISEGRÁD FOUR
}

\author{
Daniel Francois Meyer \\ University of Johannesburg, South Africa \\ Adewale Hassan \\ North-West University, South Africa
}

\begin{abstract}
A dynamic and growing manufacturing sector is critical for growth as this sector is globally known as the 'engine of growth'. The objective of this study was to assess the impact of macro-economic variables, including economic growth, producer price index (PPI), and exports on the manufacturing sector of the Visegrád countries, from 1995 to 2018. A quantitative research methodology was utilized via a panel data analysis to assess the long- and short-run relationships between the variables using econometric methods such as the Fisher-Johansen co-integration test, FMOLS and DOLS, and Granger causality tests. The main results indicated a long-run relationship between all the variables, with economic growth having the highest impact on manufacturing, while an increase in exports was also found to enhance the sector. Therefore, governments in the Visegrád group should endeavour to stimulate economic activities in support of the manufacturing sector by means of stable macro-economic policy implementation.
\end{abstract}

Keywords: Economic growth, exchange rate, exports, manufacturing, Visegrád

DOI: http://dx.doi.org/10.15549/jeecar.v7i3.561

\section{INTRODUCTION}

The manufacturing sector has been responsible for economic growth for most modern economies and the sector has been described as the engine of growth for many decades (McCausland \& Theodossiou, 2012). The research question applicable in this research was to determine which macro-economic variables impact the manufacturing sector, and the Visegrád countries were selected for the analysis. Therefore, the overall primary objective of the research was to determine the relationships between the manufacturing sector as the dependent variable with the main independent variable being economic growth, with secondary variables including the producer price index (PPI), as well as exports and exchange rates. According to Herman (2016), the fundamental strategy for many decades has 
been that the sector, as an economic base sector, represents a cornerstone for most economies, for structural change, productive jobs and sustainable economic growth. According to Haraguchi, Cheng and Smeets (2017), manufacturing is critically important for economic growth and development; however, the sector's importance and role have diminished over the last few decades with the rise of the services sector. This process resulted in a lack of industrialisation in developing countries. In looking at the future, Haraguchi et al. (2017) argued that developing countries should still have industrialisation as a key strategy for development.

Naudé and Szirmai (2012) also investigated the importance of the contribution of the manufacturing sector for economic growth and found that the manufacturing sector plays a critical role in structural transformation towards modern economies. The research identified the following aspects as important in the industrialisation process: improved integration into global value chains; identify new opportunities provided by resource-based industrialisation; the accelerating pace of technological change in manufacturing; ensure employment creation in manufacturing; and ensure strong financial institutions. The authors also argued that to facilitate structural transformation, developing countries require a manufacturing sector that can deliver quality employment, with division of labour, and linked to global value chains.

This research paper focuses on the Visegrád countries, which include Poland, Slovakia, Czech Republic and Hungary, due to the track record of economic growth over the last 30 years after communism and socialism. These countries, located in central Europe, have shared historical common ground in culture, religion, and economics over centuries. In February 1991, the four countries renewed their cooperation and the Visegrád group was subsequently formed in 1993 following the dissolution of Czechoslovakia and the establishment of the independent Czech and Slovak Republics (Káposzta \& Nagy, 2015).

\section{LITERATURE REVIEW}

The literature review consists of three components, namely definitions of concepts; theoretical foundation; and empirical results from previous studies. In terms of definitions of variables used in the study, manufacturing value-added is the dependent variable and the independent variables include GDP, which is used as the proxy for economic growth; the producer price index (PPI); the export value index; and the real effective exchange rate index. The various variables are defined to provide context to the study. Firstly, manufacturing value-added is defined by the World Bank (2020) as the net output within the manufacturing sector, after adding up all outputs and subtracting intermediate inputs. It is calculated without making deductions for depreciation of fabricated assets or depletion and degradation of natural resources. Secondly, GDP (constant 2010 US\$) is used as a proxy for economic growth in this study. According to the World Bank (2020), GDP is the sum of gross value-added by all resident producers in the economy plus any product taxes and minus any subsidies not included in the value of the products. The producer price index (PPI) is defined as a measurement of changes in prices of goods as they exit the production point or as they enter the production process (OECD). The export value index of the World Bank (2020) was used a proxy of exports and could be defined as export values are the current value of exports converted to U.S. dollars and expressed as a percentage of the average for the base year (2000). According to the IMF's International Financial Statistics, the export value indexes are derived from export volume indexes and corresponding unit value indexes of exports. Lastly, the real effective exchange rate is the nominal effective exchange rate (a measure of the value of a currency against a weighted average of several foreign currencies) divided by a price deflator or index of costs (World Bank, 2020).

This research is based on Kaldor's theory, which states that increasing returns to manufacturing production are the drivers of growth (Wells \& Thirlwall, 2003). Marconi, de Borja Reis and de Araújo, (2016) tested Kaldor's theory with the manufacturing sector and economic growth in 63 middle-income countries from 1990 to 2011. The paper incorporated two of Kaldor's laws regarding the 
hypothesis of higher growth in manufacturing that leads to higher growth in the total economy; and the law of the relationship between improvements in productivity in manufacturing leads to growth in output. This analysis indicates that increased production and exports of manufactured goods are related to increases in income levels and that the two Kaldor laws are evident within the panel of countries.

This section contains the assessment of empirical results from the literature on the relationships between the variables included in the study, and the section starts with the main variables, namely the manufacturing sector and its relationship with economic growth. The relationships with PPI, exports, and exchange rate with the main variables are listed last. The assessment is structured by first looking at developed countries, followed by developing countries. Prokop, Stejskal, and Kuvíková (2017) investigated drivers in manufacturing firms of innovation in countries including the Czech Republic, Slovakia and Hungary to gain a competitive advantage. This study is supported in an input-output analysis in Hungary by Yasmin, Refae and Eletter, (2019). Information on the three countries indicates that all of them have lost ground and have shown a decline in the international rankings of competitiveness and innovative activities in recent years. The study by Kuvíková (2017) has proven that an increase in innovation through selected drivers can significantly influence firms' growth and the total economy due to improved competitiveness. Herman (2016) analysed the importance of the manufacturing sector in the Romanian economy. Since 2000, the process and intensity of deindustrialisation in the economy have decreased, and this situation has allowed the manufacturing sector to remain the driving force for the economy. The major challenge in the sector of the economy is the relatively low level of labour productivity and innovation and technology. The sector is therefore under pressure to undergo structural change to survive in the global economy and this could be achieved via the development of a reindustrialisation strategy based on the improvement of sustainability and productivity.

Havlik (2003) assessed the restructuring of the manufacturing sector in the Central and East European (CEE) countries. Most of the countries have introduced structural changes since the period of transition at the beginning of the 1990s, leading to being competitive with other European countries related to production and employment in the manufacturing sector. The more advanced CEE countries have taken large strides in supporting technology-driven industries for exports and are in some cases on equal footing with modern European counterparts, while labour-intensive industries have growing export shares only in less advanced CEE countries such as Bulgaria, Romania and in the Baltic states. The process of export specialisation for advanced CEE countries has therefore, been reversed. McCausland and Theodossiou (2012) tested whether the manufacturing sector could still be regarded as the engine of growth in the economy for 11 major developed countries, including the U.S., Japan and U.K., spanning nearly two decades using a panel methodology. The study shows that growth in manufacturing output is an important determinant of both productivity growth and economic output growth. Although the tertiary sector is growing, it does not play a significant role in employment and economic growth. Su and Yao (2017) also investigated the role of manufacturing as a driver of economic growth for 158 middle-income economies. The study found that the manufacturing sector is still a vital industry and has linkages to most other sectors. A declining manufacturing sector has a negative impact on all sectors and the economy in both the short- and long run. Su and Yao (2017) also found that when the manufacturing sector is growing and contributes more to the economy, it also stimulates savings and contributes to technological accumulation, and lastly, they confirmed that the sector still plays the role of engine of growth in the economy for middleincome economies.

In terms of developing countries, Haraguchi et al. (2017) analysed the importance of manufacturing in economic development in developing countries and set out to determine what has led to the low levels of industrialisation. Findings indicated that the manufacturing sector value-added and employment contributions to the global 
economic output and employment had not changed significantly since 1970 . The declining manufacturing value-added and manufacturing employment share in many developing countries have been caused by a shift of manufacturing activities to a relatively small number of populous countries, thereby resulting in a concentration of manufacturing activities in specific developing countries. They also argued that the process of industrialisation of economies has continued to play a key role in the growth of developing countries and that economic development can still be achieved via industrialisation in low-income developing countries working through the stages of growth. Furthermore, Gabriel and de Santana Ribeiro (2019) analysed the relationship between economic growth and manufacturing in 115 developing countries from 1990 to 2011 using a panel vector autoregression (PVAR). The most important result from the study is that the manufacturing sector is still an engine of growth, but the sector has over time lost its relative importance in both developed and developing countries in terms of linkages to other sectors of the local economy and in terms of international trade. Szirmai and Verspagen (2015) analysed the relationship between the manufacturing sector and economic growth in developing countries from 1950 to 2005. The study tested the role of manufacturing as a driver of growth and found that manufacturing still has a significant positive effect on growth and that since 1990, the sector has had a diminishing role as a driver of growth.

In terms of the relationship between the manufacturing sector and secondary variables, namely PPI, exports and exchange rates, the following empirical results have been recorded for developed and developing countries. Cao, Dong and Tomlin (2012) tested the movements between PPI, exports and exchange rates in the Canadian environment. The results indicated that export prices are sensitive to movements in the exchange rate. Depreciation in the local currency is associated with an increase in domestic prices and an increase in export prices. Bilgin and Yilmaz (2018) assessed the relationship between PPI and manufacturing input-output networks in the U.S. from 1947 to 2018. Results indicated that manufacturing input-output networks do Granger-cause the
PPI across industries. This relationship is stronger during supply-side shocks and weaker during periods of demand shocks. Greenaway, Kneller and Zhang (2007) studied the relationship between exchange rates and exports for the manufacturing sector in the U.K. The results stated that changes in the exchange rate had insignificant effects on local firms' exports participations with a coefficient of 1.28 percent. The impact of exchange rate changes has an even smaller impact on the export activities of multinational companies.

Thorbecke and Zhang (2009) assessed the effect of exchange rate changes on China's labour-intensive manufacturing exports. The study found that an appreciation in the Chinese currency would significantly reduce exports of clothing, furniture and footwear. Furthermore, globally, Europe is the second largest exporter of labour-intensive manufactured goods after China, and the continued appreciation of the euro in relation to the Chinese currency since the beginning of the 2000s has led to a reduction in labour-intensive European exports. Radelet (1999) assessed the relationships between manufactured exports, export platforms, and economic growth. According to the results, export platforms' use and development have been successfully implemented by developing countries for exports in the manufacturing sector, especially with effective markets and increased integration with the global economy. For exports in manufacturing, factors for success include macro-economic stability, trade liberalisation, foreign direct investment (FDI), and welldeveloped infrastructure.

Nabli and Véganzonès-Varoudakis (2002) analysed the relationship between the exchange rate and competitiveness of manufactured exports in MENA countries. Results indicate that MENA countries' currencies were significantly overvalued during the 1970s and 1980s, leading to a loss of competitiveness. This situation improved somewhat in the 1990s due to the improved exchange rate and macro-economic policy and management, but currency overvaluation is still higher than in other regions. The analysis shows that the competitiveness of manufactured exports has been significantly affected by overvaluation. 
Countries where less exchange rate misalignment occurs, have achieved more diversified manufacturing sectors with more diversified exports. Golub and Ceglowski (2002) investigated real exchange rates and manufacturing competitiveness in South Africa. Results and recommendations include that especially cost competitiveness has a major impact on exports in the manufacturing sector; the real effective exchange rate has an impact on both exports and imports in the manufacturing sector, and the export-led growth strategy in the country towards manufactured products depends on a competitive real exchange rate and a growing global economy.

\section{METHODOLOGY}

To assess the relationship between the variables of interest, a functional relationship between the variables is expressed as:

$M V A=f(G D P, P P I, E X P, E X R)$

Equation (1) indicates that the manufacturing sector value-added (MVA) is a function of gross domestic product (GDP), producer price index (PPI), export value index (EXP) and real effective exchange rate (EXR). By transforming equation (1) logarithmically and into a panel data econometric specification, it becomes:

$L M V A_{i t}=\alpha_{i}+\beta_{1} G D P_{i t}+\beta_{2} P P I_{i t}+\beta_{3} E X P_{i t}+$ $\beta_{4} E X R_{i t}+\varepsilon_{i t}$

where $i$ and $t$ denote country and time dimensions respectively.

The empirical procedure entails firstly conducting stationarity tests on each of the variables. Once all the variables in the model have been confirmed stationary at first difference, a panel co-integration test can be conducted in order to determine whether or not the variables have long-run relationships. To this end, a panel co-integration test based on Johansen (1988) and Johansen and Juselius (1990) was conducted on the variables, based on the two likelihood ratio tests - trace and maximal Eigenvalue statistics, developed by Johansen and Juselius (1990).

After confirming the presence of cointegration in the data, the next step involved the estimation of the long run co-integration vector by means of panel fully modified ordinary least squares (FMOLS). According to Phillips and Moon (1999), the ordinary least squares (OLS) generate asymptotically biased results, especially in the case of a small sample and its distribution is predicated on a nuisance parameter that could emanate from regressors suffering from endogeneity and serial correlation (Pedroni, 2000, 2001). To address these issues, Pedroni $(2000,2001)$ proposed the use of FMOLS for miscellaneous co-integrated vectors, which is capable of accounting for the problems of endogeneity, serial correlation and simultaneity (Narayan \& Narayan, 2010; Ozcan, 2013). It is also described as the most appropriate technique for estimating cointegrated panel data (Hamit-Haggar, 2012). In order to check the robustness of results, equation (2) was also estimated by means of panel dynamic ordinary least squares (DOLS), which, according to Kasman and Duman (2015), generates better estimates in case of a small sample.

Since the test for co-integration only determines the presence or otherwise of longrun relationships between the variables, it does not indicate the direction of causality between them. Meanwhile, Engle and Granger (1987) argued that once there is evidence of cointegration between two or more variables, at least a one-way causality should be found between them. Therefore, to explore the direction of a causal relationship between the variables in the model, a panel-based error correction model suggested by Engle and Granger (1987) was employed, and it involves estimating the short-run error correction model by including the residuals obtained from the panel FMOLS estimates of equation (2). The specification of the Granger causality technique with the inclusion of the error correction term (ECT) is as follows:

$\Delta Z_{i t}=\Phi_{0}+\sum_{i=1}^{p-1} \Gamma_{i} \Delta Z_{i t}+\Pi Z_{i, t-1}+\varepsilon_{i t}$

where,

$\Gamma_{i}=-\sum_{j=1+1}^{p} \Phi_{j}$ and $\Pi=+\sum_{i=1}^{p} \Phi_{i-1}(4)$

where $\Delta$ is the first-difference operator, $Z_{i t}$ indicates a $5 X 1$ matrix of the manufacturing sector, GDP, PPI, export and exchange rate equations, $\Phi_{0}$ is a $5 X 1$ vector of intercepts, $\Pi$ captures the long-run information and $\varepsilon_{i t}$ 
represents the error terms.

Annual panel data for the period 1995 to 2018 was investigated for the Visegrád group, a group of four Central European economies comprising the Czech Republic, Hungary, Poland and Slovakia. The dependent variable is the manufacturing sector and it was represented by the manufacturing value-added in U.S. dollar constant prices. The explanatory variables are economic growth, denoted by the GDP in U.S. dollar constant prices, producer price index, export value index and real effective exchange rate. All the data was drawn from the World Development Indicators (WDI) of the World Bank (2020).

\section{RESULTS}

Table 1 reports a summary of the descriptive statistics of variables in the model. The mean manufacturing sector value-added and GDP stand at $\$ 33.48$ billion and $\$ 203.96$ billion, respectively, while those of producer price index, export value index and real effective exchange rate are 88.78, 340.87 and 86.19, respectively. Poland's highest manufacturing value-added figure was recorded in 2018 at $\$ 106.02$ billion, while the lowest figure of $\$ 5.28$ billion was recorded by Slovakia in 1995 . Hungary recorded the highest producer price index figure of 110.70 for 2018, while the lowest figure of 27.50 for 1995 was also recorded by the same country, which has seen its PPI figures increase steadily ever since.

Table 1. Descriptive statistics

\begin{tabular}{|l|c|c|c|c|c|c|}
\hline & Mean & Maximum & Minimum & Std. dev. & Kurtosis & Obs. \\
\hline MVA & 33.483 & 106.024 & 5.277 & 23.647 & 4.312 & 96 \\
\hline GDP & 203.962 & 631.95 & 46.643 & 146.196 & 3.75 & 96 \\
\hline PPI & 88.783 & 110.7 & 27.5 & 17.316 & 5.092 & 96 \\
\hline EXP & 340.865 & 820.9 & 45.6 & 229.165 & 1.764 & 96 \\
\hline EXR & 86.192 & 111.8 & 49.5 & 15.259 & 2.614 & 96 \\
\hline
\end{tabular}

Table 2 reports the results of the four-panel unit root test results. While Levin et al. (2002) and Breitung's (2000) tests assume common unit root process, Im et al. (2003) and ADF Fisher's (Maddala \& Wu, 1999) tests are predicated on individual unit root process. Each of the four-unit root tests operates under the null hypothesis that the variable contains a unit root, while the alternative hypothesis is that the variable is stationary. Results from all the tests indicate that all the variables became stationary only after the first difference, thereby lending support to the choice of panel FMOLS/DOLS estimation technique for the study.

Table 2. Panel unit root tests results

\begin{tabular}{|l|l|l|l|l|l|l|l|l|}
\hline \multirow{2}{*}{} & \multicolumn{2}{|c|}{ Levin, Lin \& Chu } & \multicolumn{2}{c|}{ Breitung } & \multicolumn{2}{c|}{ Im, Pesaran \& Shin } & \multicolumn{2}{c|}{ ADF Fisher } \\
\cline { 2 - 9 } & Level & $1^{\text {st }}$ Diff. & Level & $1^{\text {st }}$ Diff. & Level & $1^{\text {st }}$ Diff. & Level & $1^{\text {st }}$ Diff. \\
\hline LMVA & -0.29 & $-4.93^{* * *}$ & -0.77 & $-3.82^{* * *}$ & 1.61 & $-4.38^{* * *}$ & 3.91 & $33.63^{* * *}$ \\
\hline LGDP & -0.77 & $-3.71^{* * *}$ & -1.23 & $-2.77^{* * *}$ & 1.66 & $-3.06^{* * *}$ & 1.82 & $24.15^{* * *}$ \\
\hline LPPI & -2.34 & $-4.63^{* * *}$ & 0.39 & $-2.15^{* * *}$ & -1.09 & $-3.36^{* * *}$ & 10.99 & $25.21^{* * *}$ \\
\hline LEXP & 0.79 & $-3.29^{* * *}$ & 0.50 & $-4.16^{* * *}$ & 2.31 & $-2.81^{* * *}$ & 0.84 & $21.34^{* * *}$ \\
\hline LEXR & 0.34 & $-3.78^{* * *}$ & 1.16 & $-3.92^{* * *}$ & 1.98 & $-2.91^{* * *}$ & 2.25 & $22.41^{* * *}$ \\
\hline
\end{tabular}

Note: ${ }^{* * *}$ indicates $1 \%$ level of significance. 
The results of the Fisher-Johansen (1988) cointegration test are displayed in Table 3. The results of trace statistics accept the alternative hypothesis that there are at most two cointegrating equations at 5\% significance level, while that of max-Eigen statistics accept the alternative hypothesis that there is at most one co-integrating equation at the $1 \%$ significance level. Overall, these results confirm the existence of a long-run relationship among the variables in the model, thereby paving the way for the determination of the long-run estimates by means of panel FMOLS and DOLS.

Table 3. Co-integration test results

\begin{tabular}{|l|l|l|l|l|}
\hline No. of C.E. (s) & \multicolumn{1}{|c|}{ Trace } & p-value & Max-Eigen & p-value \\
\hline None & $70.04^{* * *}$ & 0.0000 & $34.60^{* * *}$ & 0.0000 \\
\hline At most 1 & $40.79^{* * *}$ & 0.0000 & $28.12^{* * *}$ & 0.0005 \\
\hline At most 2 & $19.17^{* *}$ & 0.0140 & 12.95 & 0.1135 \\
\hline At most 3 & 12.77 & 0.1201 & 12.14 & 0.1450 \\
\hline At most 4 & 8.995 & 0.3427 & 8.995 & 0.3427 \\
\hline
\end{tabular}

Note: ${ }^{* * *}$ and ${ }^{* *}$ indicate significance at $1 \%$ and $5 \%$, respectively.

Table 4 reports the results of panel FMOLS regression. The coefficient of LGDP is positive and statistically significant at the $1 \%$ level, which suggests that an increase in the level of GDP enhances the manufacturing sector's productivity in the long run. Looking at the elasticity coefficient of GDP, it is clear that it is higher than those of other variables and that it is the only one that is elastic, while those of the remaining variables are inelastic. This finding indicates that the manufacturing sector in the Visegrád group is more susceptible to variations in the level of GDP, relative to other variables. Specifically, a $1 \%$ increase in GDP increases the manufacturing sector by $1.39 \%$, ceteris paribus. This result underscores the importance of stimulating the countries' overall economic activities to boost the manufacturing sector. The result corroborates the finding of Singariya and Sinha (2015) and Szirmai, Prins and Schulte (2001) for India and Tanzania, respectively. The coefficient of LPPI is positive and significant at $1 \%$, which indicates the strength of the manufacturing sector in the long run. Based on the coefficient elasticity, a $1 \%$ increase in PPI leads to an increase in the manufacturing sector by $0.31 \%$. The coefficient of LEXP is positive and significant at the $5 \%$ level, bespeaking a positive impact of export on the manufacturing sector in the long run. Specifically, an increase of $1 \%$ in the export value index leads to an increase in the manufacturing sector by $0.14 \%$. This finding is supported by those of Thangavelu and Owyong (2003) and Castellani (2002) in their Singapore and Italy investigations, respectively. The coefficient is positive and statistically significant at the $10 \%$ level of significance for the real effective exchange rate. This indicates that an appreciation of the exchange rate enhances the manufacturing sector in the long run, as the coefficient elasticity of LEXR implies that a $1 \%$ appreciation in the exchange rate stimulates the manufacturing sector by $0.19 \%$. This result is supported by the finding of Faleiros et al. (2016) in their study of Brazil. Contrariwise, the result is contradictory to that of Thorbecke and Zhang (2009), who concluded that an appreciation of the RMB would largely depress China's manufacturing exports of clothing, furniture and footwear. It also contradicts Dhasmana (2013), who claimed that the issue of currency overvaluation leads to a negative effect of exchange rate appreciation on the performance of the manufacturing firms in India. Lastly, to check the robustness of results, the model was equally estimated by means of panel DOLS. The results are mainly the same as the panel FMOLS results in terms of sign and significance of variables, except the exchange rate coefficient that is insignificant. 
Table 4. Panel FMOLS and panel DOLS results

\begin{tabular}{|l|l|l|}
\hline & Panel FMOLS & Panel DOLS \\
\hline LGDP & $1.386^{* * *}(0.173)$ & $1.426^{* * *}(0.259)$ \\
\hline LPPI & $0.309^{* * *}(0.072)$ & $0.366^{* * *}(0.089)$ \\
\hline LEXP & $0.139^{* *}(0.059)$ & $0.154^{*}(0.085)$ \\
\hline LEXR & $0.191^{*}(0.102)$ & $0.067(0.155)$ \\
\hline
\end{tabular}

Notes: ${ }^{*},{ }^{* *}$ and ${ }^{* * *}$ indicate significant at $10 \%, 5 \%$ and $1 \%$ respectively; Values in parenthesis are standard errors.

The results for short-run and long-run panel Granger causality tests are displayed in Table 5. A unidirectional short-run causal relationship is found between GDP and manufacturing sector value-added, with causality running from GDP to the manufacturing sector, indicating that GDP Granger-causes manufacturing value-added. A previous result supports this finding by Singariya and Sinha (2015) that a one-way causality runs from per capita GDP to India's manufacturing sector. The results also found unidirectional short-run causality running from PPI to manufacturing sector value-added in line with the finding of Meyer and Habanabakize (2018), who claimed that a one-way causality exists from PPI to purchasing managers' index in South Africa. Furthermore, a short-run one-way causal relationship runs from PPI to export value index. A one-way short-run causality runs from each export value index and exchange rate to manufacturing value-added in a similar vein.

Furthermore, a unidirectional causality is found from real effective exchange rate to PPI. This finding is supported by Khan et al. (2018), who reported that PPI is sensitive to changes in exchange rates in the Czech Republic. Furthermore, a short-run unidirectional causality runs from real effective exchange rate to export value index and from GDP to real effective exchange rate. Meanwhile, the only bidirectional causal relationship among the variables exists between GDP and PPI. This result implies that the two variables Grangercause each other in the short run. There is, however, a case of independent causality between export value-added and GDP. This indicates that the two variables do not Grangercause each other in the short run, as no causal relationship exists between them in the short run.

Turning to the long-run results, the error correction terms' estimates show that the coefficients are negative, less than one and statistically significant for manufacturing valueadded, GDP, PPI and export value index. This implies that the variables play a crucial role in the system's adjustment process and speed from the initial deviation from the long-run equilibrium. As a result, these variables are found to have bidirectional causal relationships with each other, indicating that they Grangercause each other in the long run.

Table 5. Results of panel Granger causality

\begin{tabular}{|l|l|l|l|l|l|c|}
\hline \multirow{2}{*}{} & \multicolumn{5}{|c|}{ Short-run causality } & Long-run \\
\cline { 2 - 7 } & $\Delta$ LMVA & $\Delta$ LGDP & $\Delta$ LPPI & $\Delta$ LEXP & $\Delta$ LEXR & ECT \\
\hline$\Delta$ LMVA & & $0.2215^{* *}$ & $9.8829^{* * *}$ & $2.8427^{*}$ & $4.0266^{* *}$ & $-0.0298^{* * *}$ \\
\hline$\Delta$ LGDP & 0.0003 & & $3.9937^{* *}$ & 1.8397 & 2.1158 & $-0.0083^{* *}$ \\
\hline$\Delta$ LPPI & 0.1298 & $5.0069^{* *}$ & & 2.2216 & $4.4550^{* *}$ & $-0.0256^{* * *}$ \\
\hline$\Delta$ LEXP & 0.5110 & 0.1927 & $7.9978^{* * *}$ & & $6.3904^{* *}$ & $-0.0647^{* * *}$ \\
\hline$\Delta$ LEXR & 1.5106 & $8.8753^{* * *}$ & 0.0518 & 0.3521 & & -0.0088 \\
\hline
\end{tabular}

Note: ${ }^{*}{ }^{* *}$ and ${ }^{* * *}$ represent significance at $10 \%, 5 \%$ and $1 \%$ respectively.

\section{CONCLUSION}

This paper's primary aim was to explore the relationship between the manufacturing sector, economic growth, producer price index, export, 
and exchange rate. Panel data for the group of Visegrád Four was investigated for the period 1995 to 2018. The Fisher-Johansen cointegration test conducted confirmed that the variables converge to equilibrium in the long run. Furthermore, the panel FMOLS results show that all the explanatory variables exert positive impacts on the manufacturing sector, with GDP having the highest elasticity coefficient. Estimates from the panel DOLS regression indicate that these results are robust with the exception of the exchange rate coefficient that was found to be insignificant. With regard to the panel Granger causality tests, the empirical results found a short-run unidirectional Granger causality running from (i) GDP to manufacturing value-added and real effective exchange rate, (ii) PPI to manufacturing value-added and export value-added, (iii) export value-added to manufacturing value-added, and (iv) real effective exchange rate to manufacturing valueadded, PPI and export value-added. Furthermore, a two-way Granger causality was found between GDP and PPI, while no causal relationship was found between GDP and export value index. These results indicate, among other things, that all the variables in the model Granger-cause the manufacturing value index in the short run. It was also found that the error correction terms of manufacturing value-added, GDP, PPI and export value index are critical to the system's adjustment process, and speed and as a consequence, the four variables Grangercause each other in the long run.

These results underscore the importance of GDP growth as an important driver of the manufacturing sector. The sector can assist developed as well as developing countries with structural change to be more competitive and assist with employment and growth. An increase in export and PPI and the appreciation of exchange rate have also been found to enhance the manufacturing sector. Therefore, economies in the Visegrád Group should endeavour to continually stimulate economic activities in an optimal manner in support of the manufacturing sector by means of stable macroeconomic policy implementation.

\section{REFERENCES}

Bilgin, M., \& Yilmaz, K. (2018). Producer Price Inflation Connectedness and Input-Output Networks. Available at SSRN: https://ssrn.com/abstract=3244645.

Breitung, J. (2000). The local power of some unit root tests for panel data. In B. H. Baltagi (Ed.), Nonstationary Panels, Panel Cointegration and Dynamic Panels (pp. 161177). Elsevier: Amsterdam.

Cao, S., Dong, W. \& Tomlin, B. (2012). The sensitivity of producer prices to exchange rates: insights from micro data. Bank of Canada Working Paper 2012-20.

Castellani, D. (2002). Export behavior and productivity growth: Evidence from Italian manufacturing firms. Weltwirtschaftliches Archiv 138, 605-628.

Dhasmana, A. (2013). Real Effective Exchange Rate and Manufacturing Sector Performance: Evidence from Indian Firms. IIM Bangalore Research Paper No. 412. Available at SSRN: https://ssrn.com/abstract=2284077.

Engle, R.F. \& Granger, C.W. 1987. Co-integration and error correction: representation estimation, and testing. Econometrica, 55(2): 251-276.

Faleiros, J.P., Domingos da Silva, J.C. \& Nakaguma, M.Y. (2016). Evaluating the effect of exchange rate and labor productivity on import penetration of Brazilian manufacturing sectors, Economia, 17(1), 3-22.

Gabriel, L.F. \& de Santana Ribeiro, L.C. (2019). Economic growth and manufacturing: An analysis using Panel VAR and intersectoral linkages. Structural Change and Economic Dynamics, 49, 43-61.

Golub, S.S. \& Ceglowski, J. (2002). South African real exchange rates and manufacturing competitiveness. South African Journal of Economics, 70(6), 1047-1075.

Greenaway, D., Kneller, R. \& Zhang, X. (2007). Exchange rates and exports: Evidence from manufacturing firms in the U.K. University of Nottingham Discussion Paper 07/13.

Hamit-Haggar, M. (2012). Greenhouse gas emissions, energy consumption and 
economic growth: A panel co-integration analysis from Canadian industrial sector perspective. Energy Economics, 34(1), 358364.

Haraguchi, N., Cheng, C.F.C. \& Smeets, E. (2017). The importance of manufacturing in economic development: Has this changed? World Development, 93, 293-315.

Havlik, P. (2003). Restructuring of manufacturing industry in the Central and East European Countries. Prague Economic Papers, 1, 18-35.

Herman, E. (2016). The importance of the manufacturing sector in the Romanian economy. Procedia Technology, 22, 976-983.

Im, K.S., Pesaran, M.H. \& Smith, Y. (2003). Testing unit Roots in heterogeneous panels, Journal of Econometrics, 115, 53-74.

Johansen, S. (1988). Statistical analysis of cointegrating vectors. Journal of Economic Dynamics and Control, 12, 231-254.

Johansen, S. \& Juselius, K. (1990). Maximum likelihood estimation and inference on cointegration with application to the demand for money. Oxford Bulletin of Economics and Statistics, 52, 169-210.

Kasman, A. \& Duman, Y.S. (2015). CO2 emissions, economic growth, energy consumption, trade and urbanization in new E.U. member and candidate countries: a panel data analysis. Economic Modelling, 44, 97-103.

Káposzta, J. \& Nagy, H. (2015). Status report about the progress of the Visegrad countries in relation to Europe 2020 targets. European Spatial Research and Policy, 22(1), 81-99.

Khan, K., Su, C., Tao R. \& Chu, C. (2018). Is there any relationship between producer price index and consumer price index in the Czech Republic? Economic Research, 31(1), 1788-1806.

Levin, A., Lin, C. F. \& Chu, C. (2002), Unit root tests in panel data: asymptotic and finitesample properties, Journal of Econometrics, 108, 1-24.

Maddala, G.S. \& Wu, S. (1999), A comparative study of unit root tests with panel data and a new simple test, Oxford Bulletin of Economics and Statistics, 61, 631-652.
McCausland, W.D. \& Theodossiou, I. (2012). Is manufacturing still the engine of growth? Journal of Post Keynesian Economics, 35(1), 79-92.

Marconi, N., de Borja Reis, C. F. \& de Araújo, E. C. (2016). Manufacturing and economic development: The actuality of Kaldor's first and second laws. Structural Change and Economic Dynamics, 37, 75-89.

Meyer, D.F., \& Habanabakize, T. (2018). Analysis of Relationships and Causality between Consumer Price Index (CPI), the Producer Price Index (PPI) and Purchasing Manager's Index (PMI) in South Africa. Journal of Economics and Behavioural Studies, 10, 115.

Nabli, M.K. \& Véganzonès-Varoudakis, M.A. (2002). Exchange rate regime and competitiveness of manufactured exports: The case of MENA countries. World Bank, Office of the Chief Economist.

Narayan, P.K. \& Narayan, S. (2010). Carbon dioxide emissions and economic growth: panel data evidence from developing countries. Energy Policy, 38(1), 661-666.

Naudé, W., \& Szirmai, A. (2012). The importance of manufacturing in economic development: Past, present and future perspectives, MERIT Working Papers 2012-041, United Nations University - Maastricht Economic and Social Research Institute on Innovation and Technology (MERIT).

OECD. Glossary of Statistical Terms. Source: http://stats.oecd.org/glossary.

Ozcan, B. (2013). The nexus between carbon emissions, energy consumption and economic growth in Middle East countries: a panel data analysis. Energy Policy, 62, 1138-1147.

Pedroni, P. (2000). Fully Modified OLS for Heterogeneous Co-integrated Panels. In Baltagi, B. H. (Ed.), Nonstationary Panels, Panel Cointegration and Dynamic Panels, 15, Amsterdam: Elsevier, 93-130.

Pedroni, P. (2001). Purchasing power parity tests in co-integrated panels. Review of Economics and Statistics, 83(4), 727-731. 
Phillips, P.C. \& Moon, H.R. (1999). Linear regression limit theory for nonstationary panel data. Econometrica, 67(5), 1057-1111.

Prokop, V., Stejskal, J. \& Kuvíková, H. (2017). The different drivers of innovation activities in European countries: A comparative study of Czech, Slovak, and Hungarian manufacturing firms. Ekonomický časopis SAV, 65(1).

Radelet, S. (1999). Manufactured exports, export platforms, and economic growth. Consulting Assistance on Economic Reform (CAER) II Discussion Paper, 43.

Su, D. \& Yao, Y. (2017). Manufacturing as the key engine of economic growth for middleincome economies. Journal of the Asia Pacific Economy, 22(1), 47-70.

Singariya, M.R. \& Sinha, N. (2015). Relationships among per capita GDP, agriculture and manufacturing sectors in India. Journal of Finance and Economics, 3(2), 36-43.

Szirmai, A. \& Verspagen, B. (2015). Manufacturing and economic growth in developing countries, 1950-2005. Structural Change and Economic Dynamics, 34, 46-59.

Szirmai A., Prins M. \& Schulte W. (2001) Measuring Manufacturing Performance in Tanzania: GDP, Employment and Comparative Labour Productivity, 1961-95. In: Szirmai A., Lapperre P. (Eds) The Industrial Experience of Tanzania. Palgrave Macmillan, London

Thangavelu, S.M. \& Owyong, D.T. (2003). The impact of export growth and scale economies on productivity in Singapore's manufacturing industries. Journal of Economic Studies, 30(6), 623-635.

Thorbecke, W. \& Zhang, H. (2009). The effect of exchange rate changes on China's labour-intensive manufacturing exports. Pacific Economic Review, 14(3), 398-409.

Wells, H. \& Thirlwall, A.P. (2003). Testing Kaldor's growth laws across the countries of Africa. African Development Review, 15(2-3), 89-105.

World Bank. (2020). World Development Indicators. https://data.worldbank.org/

Yasmin, T., Refae, G.A., \& Eletter, S. (2019). Sectoral productivity in Hungarian economy: an input-output linkages approach. Journal of Eastern European and Central Asian Research (JEECAR), 6(2), 344355. 


\section{ABOUT THE AUTHORS}

Daniel Francois Meyer, email: dfmeyer@uj.ac.za

Prof Daniel Meyer is a research professor in the College of Business and Economics at the University of Johannesburg, South Africa. Daniel is a specialist in regional and local economic development analysis and policy development. He has developed various measurement tools, indexes and scales to analyse regional economies. He has authored more than 100 internationally peer-reviewed research papers since 2015 and has also presented more than 60 international conference papers, including many keynote addresses. His research is multi-disciplinary through the combination of development economics and public management and governance. $\mathrm{He}$ has established a large international network of research partners worldwide with a strong focus on the Visegrad group of countries. He has also successfully completed and delivered more than 40 regional development strategies for local governments and provincial governments. $\mathrm{He}$ is also involved in various community development projects in the communities where he lives. During his academic career, he has received several awards, which include: most inspiring lecturer in 2012; Vice-Chancellor's award for community engagement via the Vaal LED warrior initiative in 2016; media person of the year in 2016; and most productive senior researcher on the NWU Vaal campus in 2016, 2017 and 2018; and most productive senior researcher in the NWU Faculty of Economic and Management Sciences in 2019. His motto in life is "give more than you take."

Dr. Adewale Hassan is a Post-doctoral research fellow at TRADE research entity, North-West University, South Africa. His research interests include macroeconomic policy analysis, energy economics, and development economics. $\mathrm{He}$ is also a specialist in econometric research and economic modeling, for which he has facilitated several training sessions. He has authored more than ten internationally peer-reviewed research papers and has presented several international conference papers. He is also involved in various peer review activities with several high impact journals. He has attended a good number of trainings and workshops on econometric research and economic modelling both locally and internationally. 